\title{
Physicochemical Performance of Collagen Modified by Melissa officinalis Extract
}

\author{
Katarzyna Adamiak ${ }^{1,2}$, Marzanna Kurzawa ${ }^{3}$ and Alina Sionkowska ${ }^{2, *(D)}$ \\ 1 WellU sp.z.o.o, Wielkopolska 280 Street, 81-531 Gdynia, Poland; kadamiak@wellu.eu \\ 2 Department of Biomaterials and Cosmetics Chemistry, Faculty of Chemistry, \\ Nicolaus Copernicus University in Torun, Gagarin 7 Street, 87-100 Torun, Poland \\ 3 Department of Analytical Chemistry and Applied Spectroscopy, Faculty of Chemistry, \\ Nicolaus Copernicus University in Torun, Gagarin 7 Street, 87-100 Torun, Poland; jmk@umk.pl \\ * Correspondence: alinas@umk.pl
}

check for updates

Citation: Adamiak, K.; Kurzawa, M.; Sionkowska, A. Physicochemical Performance of Collagen Modified by Melissa officinalis Extract. Cosmetics 2021, 8, 95. https://doi.org/10.3390/ cosmetics 8040095

Academic Editor:

Isabel Martins de Almeida

Received: 10 September 2021

Accepted: 27 September 2021

Published: 30 September 2021

Publisher's Note: MDPI stays neutral with regard to jurisdictional claims in published maps and institutional affiliations.

Copyright: (c) 2021 by the authors. Licensee MDPI, Basel, Switzerland. This article is an open access article distributed under the terms and conditions of the Creative Commons Attribution (CC BY) license (https:// creativecommons.org/licenses/by/ $4.0 /)$.

\begin{abstract}
Collagen-based materials are widely used as adhesives in medicine and cosmetology. However, for several applications, their properties require modification. In this work, the influence of Melissa officinalis on the properties of collagen films was studied. Collagen was extracted from Silver Carp skin. Thin collagen films were prepared by solvent evaporation. The structure of films was researched using infrared spectroscopy. The surface properties of films were investigated using Atomic Force Microscopy (AFM). Mechanical properties were measured as well. Antioxidant activity was determined by spectrophotometric methods using DPPH free radicals, FRAP, and CUPRAC methods. Total phenolic compounds were determined by the Folin-Ciocalteau method. It was found that the addition of Melissa officinalis modified the roughness of collagen films and their mechanical properties. Moreover, the obtained material has antioxidant properties. The parameters mentioned above are very important in potential applications of collagen films containing Melissa officinalis in cosmetics.
\end{abstract}

Keywords: collagen; Melissa officinalis extract; incorporation; natural extract; adhesives; antioxidant activity

\section{Introduction}

Collagen comprises one of the most appropriable biomaterials due to its eminent biocompatibility, biodegradability, natural origin, and non-genicity. It is used in medical applications such as drug delivery systems, material matrices, and scaffolds in tissue engineering [1-5]. Collagen is the main component of the extracellular matrix containing fibrils and microfibrils that enable cell attachment and their migration in the materials as well as modifying their mechanical properties [6]. From a biomaterial and cosmetic perspective, the most important types of collagens are type I, which constitutes the major component of the skin, ligament, and tendon tissue, type II-the cartilage collagen, and type III, which is eminent for blood vessels [7-9]. Evaluating the capability of the materials is all about the role and function that the potential device needs to perform. The structure of collagen type I is described by three chains that form a triple-helical conformation. Each of the polypeptide chains creates hydroxyproline II type helix. It is firmed by amino acid content. Chains are furled in right inclination to form a triple helix. The amino acid chain can be featured as a Gly-X-Y sequence, where X constitutes proline, while $Y$ is represented by hydroxyproline [10-15]. Collagen resistance requires enhancing and optionally addition of functional substances [16]. Nowadays, the possibilities of green chemistry are immeasurable and may offer several solutions. Testing new natural crosslinkers may lead to new solutions that can meet the expectations of modern collagen biomaterials. However, the structure of modified collagen is both plant-dependent and 
type-of-extract-dependent, so it is necessary to research each plant extract and its influence on collagen properties separately.

Melissa officinalis, also call a lemon balm, belongs to Lamiaceae family [17]. It was used as traditional herbal medicine as an antibacterial, analgetic, spasmolytic, sedative, tonic, diuretic, antiparasitic, and antiviral agent [18]. There are several melissa applications in the biomedical and cosmetics fields. The extract of melissa was used in asthma [19,20], bronchitis [21], amenorrhea [22], arrhythmias [23], ulcers, and wound treatment [24,25]. Melissa officinalis extract was utilized in neurological pathologies as insomnia, epilepsy, depression, psychosis, and hysteria due to its sedative properties [26,27]. The development of new biomaterials with antifungal, antiparasitic, and antibacterial characteristics [28-30] comprises a promising issue in topical treatment.

The antioxidative potential of lemon balm has been documented due to its chemical composition [31-34]. Melissa officinalis extract contains flavonoids, gallic acid, phenolic acid, and rosmaric acid. Focusing on Melissa officinalis leaf extract, the main flavonoids are quercetin, rhamnocitrin, and luteolin. Polyphenolic compounds which can be found in Melissa officinalis leaf extract are as follows: caffeic acid, protocatechuic acid, and rosmarinic acid [35]. There are also mono-, triterpenes, and sesquiterpenes present alongside tannins and essential oils [36].

The Melissa officinalis antiviral effect against HSV-1 and HSV-2 due to the presence of monoterpenaldehydes and citronellal have been examined. The results have shown that melissa is affecting the virus before the adsorption into the host cell [37]. This effect is also due to caffeic, rosmarinic, and ferulic acids, which are present in melissa.

Topically, melissa has also been tested in balm form that turned out to be effective in the herpes simplex infection treatment. It has prevented spreading the infection and also mellowed the symptoms like itching, straining, and redness of the skin $[38,39]$. As the research has shown, hydroalcoholic extract of lemon balm leaves indicated activity against the herpes simplex virus type 2 . The antiviral activity was compared to acyclovir activity. It has also been mentioned that Melissa officinalis extract had reduced cytopathic effect to HSV-2 in a nontoxic amount [40].

The antimicrobial activity of Melissa officinalis was documented against Escherichia coli, Pseudomonas aeruginosa, Proteus mirabilis [41], and resistant strain Shigellasonei [42]. Ethanol, water, or ethyl acetate extracts of Melissa officinalis ameliorate antibiotic activity for streptomycin, amoxicillin, tetracycline, and chloramphenicol. The raised biological activity is dictated by the presence of phenol and flavonoid content [43-45].

From the biomaterial perspective, the most desirable functions of the adhesive material are antimicrobial, antiviral, antifungal, and antioxidative activity, which can be provided by the addition of the Melissa officinalis extract. Additionally, the anti-inflammatory properties of the mentioned natural extract help to reduce potential swelling [46].

Melissa officinalis has various applications in pharmacognosy, cosmetics, and biomaterial fields due to its antimicrobial, antifungal, antiviral, and antioxidative properties. In cosmetic formulations, melissa protects the skin from oxidative stress, irradiations, and blue light. Due to high content of rosmaric acid, melissa shows antioxidant activity by reducing ROS, which prevents UV damage. Polyphenols and flavonoids in Melissa officinalis demonstrate radical scavenging activity comparable to ascorbic acid, whereas tyrosinase inhibitory activity by melissa extract was higher than arbutin. This makes Melissa officinalis an effective antioxidant, anti-inflammatory, and whitening cosmetic ingredient.

The aim of this research was to prepare collagen materials modified by Melissa officinalis. The mentioned above materials are designed for cosmetic applications. In this work, fish collagen was used, which is already commercially applied in cosmetic products. To the best of our knowledge, the influence of Melissa officinalis on collagen properties has not been studied yet. 


\section{Materials and Methods}

\subsection{Materials}

Fish collagen was delivered by WellU sp.z.o.o. (Gdynia, Poland). Such collagen is used in cosmetic formulations. Melissa officinalis dry extract was delivered by Greenvit (Zambrów, Poland).

\subsection{Mixture Preparation}

\subsubsection{Collagen Solution Preparation}

Collagen (Col) was extracted from Silver Carp skin. Residues such as fat tissue, meat, or scales were obviated manually and purified with chilled tap water to get rid of the clinging tissues. Then, the material was disinfected with a $3 \%$ hydrogen peroxide water solution. Side elements were rinsed thoroughly. The cleared skin was placed in $0.1 \mathrm{M}$ acetic acid solution and left for three days to extract the collagenous proteins. The obtained solution was pressed through the properly chosen material, which allowed for collagen separation [47]. In the next stage, samples were lyophilized (ALPHA 1-2 LDplus, CHRIST, $-20^{\circ} \mathrm{C}, 100 \mathrm{~Pa}, 48 \mathrm{~h}$ ), then lyophilized collagen was dissolved in $0.1 \mathrm{M}$ acetic acid at the $5 \mathrm{mg} / \mathrm{mL}$ concentration.

\subsubsection{Melissa Solution Preparation}

First, the dry Melissa officinalis (ML) extract weighing $0.3702 \mathrm{~g}$ was transferred quantitatively into a $10 \mathrm{~mL}$ volumetric flask, then filled to $10 \mathrm{~mL}$ with water and mixed to dissolution. Then prepared in the previous stage collagen solution was moved to a $25 \mathrm{~mL}$ volumetric flask. Melissa water solution in the volume of $1 \mathrm{~mL}$ was transferred to the collagen solution and mixed. The amount of melissa extract in collagen was $29.62 \%$.

\subsection{Film-Forming Stage}

Collagen solution as control and mixed collagen-melissa solution were perched into the adequate plates, previously checking the proper surface level. Collagen solutions filled the plated evenly. Then the samples were left to dry for six days. Dried films were carefully detached from the plates, and their properties were investigated.

\subsection{Infrared Spectroscopy (IR)}

Infrared spectra were examined by Nicolet iS10 spectrophotometer equipped with an ATR device with a germanium crystal (Thermo Fisher Scientific, Waltham, MA, USA). All the spectra were recorded with the resolution of $4 \mathrm{~cm}^{-1}$ with 64 scans. The spectra were evaluated in the range of $400-4000 \mathrm{~cm}^{-1}$. The data were obtained using the Omnic Spectra 2009 program.

\subsection{Scanning Electron Microscopy (SEM)}

Scanning Electron Microscopy (SEM) was carried out by Scanning Electron Microscope (SEM) (LEO Electron Microscopy Ltd., Cambridge, UK). Micrographs of all samples were taken at $300 \times$ magnification.

\subsection{Energy-Dispersive X-ray Spectroscopy (EDX)}

Energy-Dispersive X-ray Spectroscopy (EDX) was performed using the EnergyDispersive X-ray Spectrometer EDX Quantax 200 with detector XFlask 4010, Bruker, AXC, Germany, to assess the elemental composition of a material.

\subsection{Atomic Force Microscopy (AFM)}

The surface structure of collagen/melissa materials was examined by an Atomic Force Microscope. The pictures were obtained by MultiMode Scanning Probe Microscope Nanoscope IIIa (Digital Instruments Veeco Metrology Group, Santa Barbara, CA, USA) operating in the tapping mode, in air, in room temperature. Surface images were acquired at fixed resolution $(512 \times 512$ data points $)$ with a scan rate of $1.97 \mathrm{~Hz}$. Silicon tips with 
a spring constant of $2-10 \mathrm{~N} / \mathrm{m}$ were used. Roughness parameters were calculated from $10 \mu \mathrm{m} \times 10 \mu \mathrm{m}$ scanned areas using Nanoscope software.

\subsection{Mechanical Properties}

The shaped pieces cut from collagen and collagen-melissa films were prepared using manual press Optimum DDP10 (Germany). Mechanical properties of collagen and collagen/melissa films like Young modulus and tensile strength were tested using a Zwick\&Roell Z.0.5 testing machine in constant condition at room temperature. Parameters of the program: $200 \mathrm{~mm} / \mathrm{min}$ speed starting position, $0.1 \mathrm{~N}$ initial force, $5 \mathrm{~mm} / \mathrm{min}$ speed of the initial force. In this study, seven samples of each kind of film were measured to evaluate average mechanical parameters.

\subsection{Determination of Antioxidant Capacity}

\subsubsection{Preparation of Samples}

Collagen film and collagen film with lemon balm (Melissa officinalis) extract weighing from 0.0030 to $0.0060 \mathrm{~g}$ were placed in a $10 \mathrm{~mL}$ graduated flask. About $5 \mathrm{~mL}$ of $0.1 \mathrm{M}$ acetic acid solution was added to dissolve the samples. The samples were placed in an ultrasonic bath for approximately $0.5 \mathrm{~h}$. After dissolving, the contents of the flask were diluted with distilled water to the mark.

2.9.2. Spectrophotometric Method for Determination of the Total Polyphenols Content Using the Folin-Ciocalteu Reagent (F-C Method)

A UV-Vis spectrophotometer Shimadzu UV-1601 (Japan) double beam spectrophotometer was used to measure the absorbance. Folin-Ciocalteau reagents caffeic acid $(50 \mu \mathrm{g} / \mathrm{mL})$, and $\mathrm{Na}_{2} \mathrm{CO}_{3}(0.13 \mathrm{~g} / \mathrm{mL})$ were used. The measurements were done in standard glass cuvettes.

\section{Preparation of the Calibration Curve}

To the $10 \mathrm{~mL}$ volumetric flask $0.00,0.10,0.20,0.30,0.60,0.70$, and $0.80 \mathrm{~mL}$ of $50 \mu \mathrm{g} / \mathrm{mL}$ caffeic acid solution were added. Then $0.5 \mathrm{~mL}$ of Folin's reagent was added and set aside in a dark place for $5 \mathrm{~min}$. After this time, $4 \mathrm{~mL}$ of water was added, mixed, and $1 \mathrm{~mL}$ of a sodium carbonate solution was added. The flasks were made up to the mark with water. The absorbance of the sample was measured after $30 \mathrm{~min}$ at $\lambda=725 \mathrm{~nm}$ against a blank reference $\left(0.5 \mathrm{~mL} \mathrm{~F}-\mathrm{C}\right.$ reagent $+1 \mathrm{~mL} \mathrm{Na}_{2} \mathrm{CO}_{3}$ solution and make up to $10 \mathrm{~mL}$ with distilled water). On the basis of the measurement and the obtained results, the dependence of absorbance on the concentration of caffeic acid was plotted.

Sample Analysis

The volume of $1 \mathrm{~mL}$ of the previously prepared collagen film solution and collagen film with lemon balm extract solution was taken into $10 \mathrm{~mL}$ volumetric flasks, $0.5 \mathrm{~mL}$ of the $\mathrm{F}-\mathrm{C}$ reagent was added and left in a dark place. After $3 \mathrm{~min}, 1 \mathrm{~mL}$ of $\mathrm{Na}_{2} \mathrm{CO}_{3}$ solution was added and made up to the mark with distilled water. After $30 \mathrm{~min}$, the absorbance at $\lambda=725 \mathrm{~nm}$ was measured against a reference blank. For each tested film, five parallel determinations were made.

\subsubsection{Determination of Antioxidant Activity by FRAP Method}

For the determination of antioxidant capacity by FRAP method, the UV-Vis spectrophotometer previously mentioned was used. The following reagents were used: acetic buffer solution, $\mathrm{pH}=3.6 ; 20 \mathrm{mM}$ iron(III) chloride solution, $10 \mathrm{mM}$ solution of 2,4,6-tripyridyls-triazine (TPTZ); the MR-FRAP reaction mixture was prepared as follows: $25 \mathrm{~mL}$ of an acetic buffer solution at $\mathrm{pH} 3.6$ was pipetted into a $50 \mathrm{~mL}$ beaker; $2.5 \mathrm{~mL}$ of TPTZ solution $(10 \mathrm{mmol} / \mathrm{L})$ and $2.5 \mathrm{~mL}$ of iron(III) chloride solution $(20 \mathrm{mmol} / \mathrm{L})$. All the reagents were mixed and incubate at $40^{\circ} \mathrm{C}$ (for $15 \mathrm{~min}$ ). $0.001 \mathrm{M}$ 6-hydroxy-2,5,7,8-tetramethylchroman2-carboxylic acid solution (Trolox) was used as standard. 


\section{Preparation of the Calibration Curve}

Into $10 \mathrm{~mL}$ volumetric flasks $0.05,0.10,0.15,0.20$, and $0.25 \mathrm{~mL}$ of the Trolox solution at a concentration of $\mathrm{c}=0.001 \mathrm{M}$ was pipetted. Then, $2 \mathrm{~mL}$ of the reaction mixture was pipetted into each of them and made up to the mark with distilled water. The prepared solutions were left for $20 \mathrm{~min}$ in a dark place. After this time, the absorbance of the solutions was measured at the wavelength $\lambda=593 \mathrm{~nm}$, using the blank as a reference.

\section{Sample Analysis}

Into $10 \mathrm{~mL}$ volumetric flasks, $3 \mathrm{~mL}$ of analyzed solution and $2 \mathrm{~mL}$ of the reaction mixture were added and next they were filled up to the mark with distilled water. The prepared solutions were placed for $15 \mathrm{~min}$ in a dark place. After this time, the absorbance of the solutions was measured at the wavelength $\lambda=593 \mathrm{~nm}$, using the blank as a reference.

\subsubsection{Determination Antioxidant Activity by CUPRAC Method}

For the determination of antioxidant capacity by the CUPRAC method, the UVVis spectrophotometer previously mentioned was used. The following reagents were used: $0.0075 \mathrm{M}$ neocuproine solution, $0.01 \mathrm{M}$ copper chloride solution, $1 \mathrm{M}$ acetate buffer $(\mathrm{pH}=7.0)$, and caffeic acid solution at a concentration of $50 \mathrm{mg} / \mathrm{L}$ as standard.

\section{Preparation of the Calibration Curve}

The volume of $2 \mathrm{~mL}$ of copper(II) chloride solution, neocuproine solution, and acetate buffer were pipetted into $10 \mathrm{~mL}$ volumetric flasks. Then $0.05,0.10,0.25,0.30$, and $0.35 \mathrm{~mL}$ of caffeic acid was added and made up to the mark with distilled water. The flasks were placed in a dark place for $30 \mathrm{~min}$. After this time, the absorbance was measured at a wavelength of $\lambda=450 \mathrm{~nm}$ against the blank.

\section{Sample Analysis}

For the measurement of the antioxidant activity of the studied films, $2 \mathrm{~mL}$ copper(II) chloride, neocuproine, and buffer were pipetted into $10 \mathrm{~mL}$ volumetric flasks. Then, $2 \mathrm{~mL}$ of the tested film solutions were added to the flasks. The flasks were made up with distilled water and set aside in a dark place for $30 \mathrm{~min}$. After this time, the absorbance was measured at a wavelength of $\lambda=450 \mathrm{~nm}$ against the blank.

\subsubsection{Determination of Antioxidant Activity by DPPH Method}

For the determination of antioxidant capacity by the DPPH method the UV-Vis spectrophotometer previously mentioned was used. The following reagents were used: $0.304 \mathrm{M}$ solution of 2,2'-diphenyl-1-picrylhydrazyl (DPPH), $0.1 \mathrm{mM}$ solution of 6-hydroxy-2,5,7,8tetramethylchroman-2-carboxylic acid (Trolox).

\section{Preparation of the Calibration Curve}

In order to prepare a calibration curve, the following volumes of Trolox were pipetted into $10 \mathrm{~mL}$ volumetric flasks: $0.00,1.00,4.00,7.00,8.00$, and $10.00 \mathrm{~mL}$. Then the flasks were made up to volume with ethanol. Next, $1.5 \mathrm{~mL}$ of ethanol, $0.5 \mathrm{~mL}$ of the previously prepared DPPH solution, and $0.5 \mathrm{~mL}$ each of Trolox solutions of increasing concentration were added to plastic measuring cuvettes. A blank test was also made by adding $2 \mathrm{~mL}$ of ethanol and $0.5 \mathrm{~mL}$ of DPPH solution to the measuring cuvette. The solutions prepared in this way were placed for $15 \mathrm{~min}$ in a dark place. After this time, the absorbance was measured at a wavelength of $\lambda=517 \mathrm{~nm}$. Ethanol was used as a reference. In order to draw the calibration curve, the percentage of the scavenged radical was calculated, which is expressed by the formula:

$$
\% \mathrm{DPPH}=\left(\frac{A_{0}-A_{n}}{A_{0}}\right) \times 100 \%
$$


where: $A_{0}$-absorbance of the blank sample (Trolox volume $=0.00 \mathrm{~mL}$ ), $A_{n}$ —absorbance of the sample.

\section{Sample Analysis}

In order to test the antioxidant activity of the tested collagen films, $1.5 \mathrm{~mL}$ of ethanol, $0.5 \mathrm{~mL}$ of DPPH solution and $0.5 \mathrm{~mL}$ of the tested solution were pipetted into plastic cuvettes. A blank test was also performed by measuring $2 \mathrm{~mL}$ of ethanol and $0.5 \mathrm{~mL}$ of DPPH solution into a plastic cuvette. The blank test was performed separately for each measurement. The solutions prepared in this way were placed in a dark place for $15 \mathrm{~min}$. After this time, the absorbance against ethanol as reference was measured at a wavelength of $\lambda=517 \mathrm{~nm}$.

\section{Results}

\subsection{Physicochemical Properties}

To affirm the presence of melissa in collagen films, the infrared spectra were registered. Listing of IR bands have been discussed (Table 1). The IR spectra have been shown in Figure 1 .

Table 1. Wavenumbers for bands position and proper bonds in exact types of chemical compounds in collagen film.

\begin{tabular}{cccc}
\hline IR Band & Stretching & $\begin{array}{c}\text { Band Position for } \\
\text { Collagen } \mathbf{( \mathbf { c m } ^ { - 1 } )}\end{array}$ & $\begin{array}{c}\text { Band Position for } \\
\left.\text { Collagen/Melissa } \mathbf{( c m}^{-\mathbf{1}}\right)\end{array}$ \\
\hline amide A & $\mathrm{N}-\mathrm{H}, \mathrm{OH}$ & 3291 & 3298 \\
amide I & $\mathrm{C}=\mathrm{O}$ & 1631 & 1632 \\
amide II & $\mathrm{N}-\mathrm{H}$ & 1541 & 1543 \\
amide III & $\mathrm{C}-\mathrm{N}$ & 1233 & 1234 \\
carboxylic acid & $\mathrm{O}=\mathrm{H}$ & - & 1377 \\
phenol group & & & \\
\hline
\end{tabular}

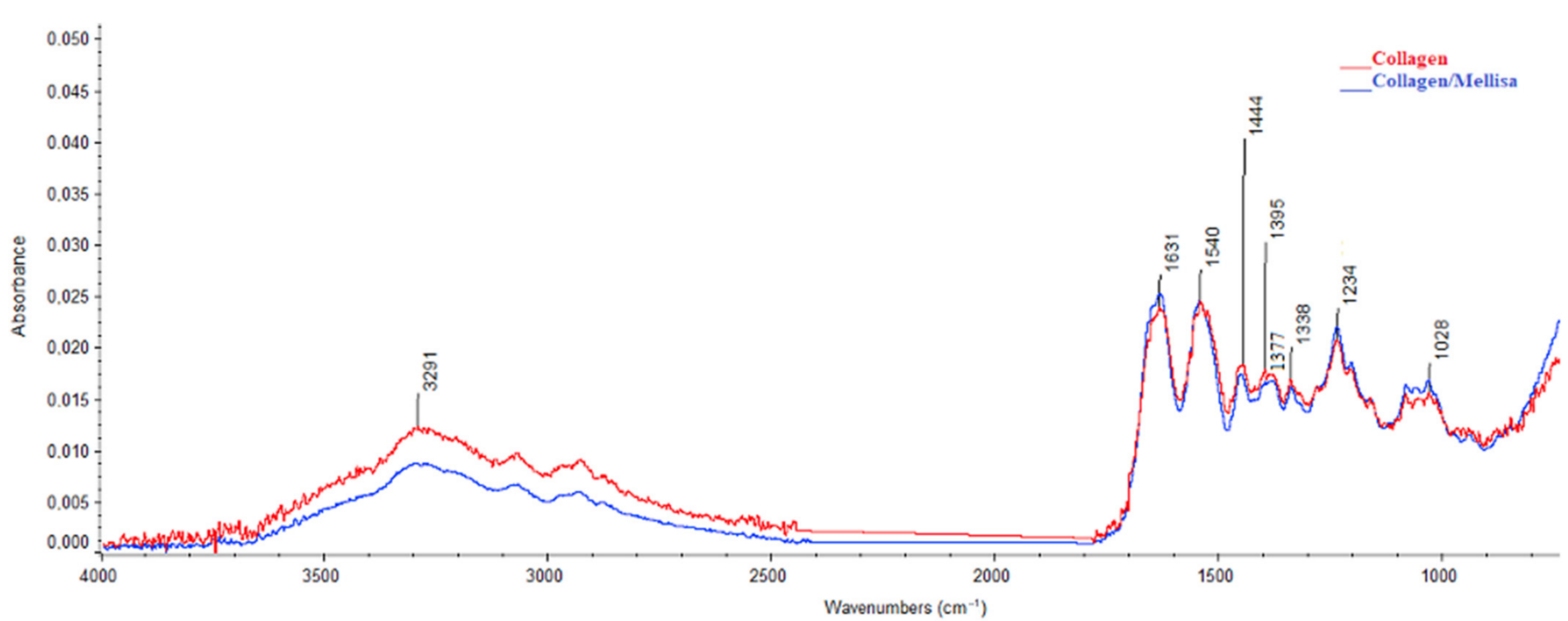

Figure 1. IR spectra of collagen/melissa film and collagen film (control) from 4000 to $500 \mathrm{~cm}^{-1}$.

The band at $3291 \mathrm{~cm}^{-1}$ represents amide A (N-H stretching) and OH in collagen [48-52]. Collagen strands are represented in $1631 \mathrm{~cm}^{-1}$ for amide I through $\mathrm{C}=\mathrm{O}$ bond, $1541 \mathrm{~cm}^{-1}$ : amide II (N-H), and $1233 \mathrm{~cm}^{-1}$ : amide III (C-N). As we can see in Figure 1 for the collagen/melissa sample the following bands can be observed: Amide $\mathrm{A}$ and $\mathrm{O}-\mathrm{H}$ groups at around $3298 \mathrm{~cm}^{-1}$ and new band at $1377 \mathrm{~cm}^{-1}$. The mentioned new band may represent $\mathrm{O}-\mathrm{H}$ bending in carboxylic acid and $\mathrm{O}-\mathrm{H}$ stretching due to phenol group in gallic acid, 
phenolic acid, and rosmaric acid. For collagen with the addition of melissa extract the shift of amide A band was observed (from $3291 \mathrm{~cm}^{-1}$ to $3298 \mathrm{~cm}^{-1}$ ). It may suggest the interaction between collagen and extract components via hydrogen bonds. In fact, the melissa extract contains flavonoids, gallic acid, phenolic acid, and rosmaric acid, which can form several hydrogen bonds with collagen molecules [35-37]. The shift of amide A can also be caused by the different amount of water bounded to collagen in the presence of melissa. For amide I and amide II bands we did not observe the shift. This fact may suggest that the secondary structure of collagen type I was not changed after the addition of melissa to collagen solution. The structure of collagen in general before and after the addition of melissa is very similar, except the new band at $1377 \mathrm{~cm}^{-1}$.

\subsection{Morphological Properties}

For investigation of the surface structure of prepared films, SEM and EDX microscopy were performed. Figure 2 represents the SEM image of the collagen/melissa film. The film exhibits a smooth and heteroclite surface. Collagen fibrils are in loose conformation.

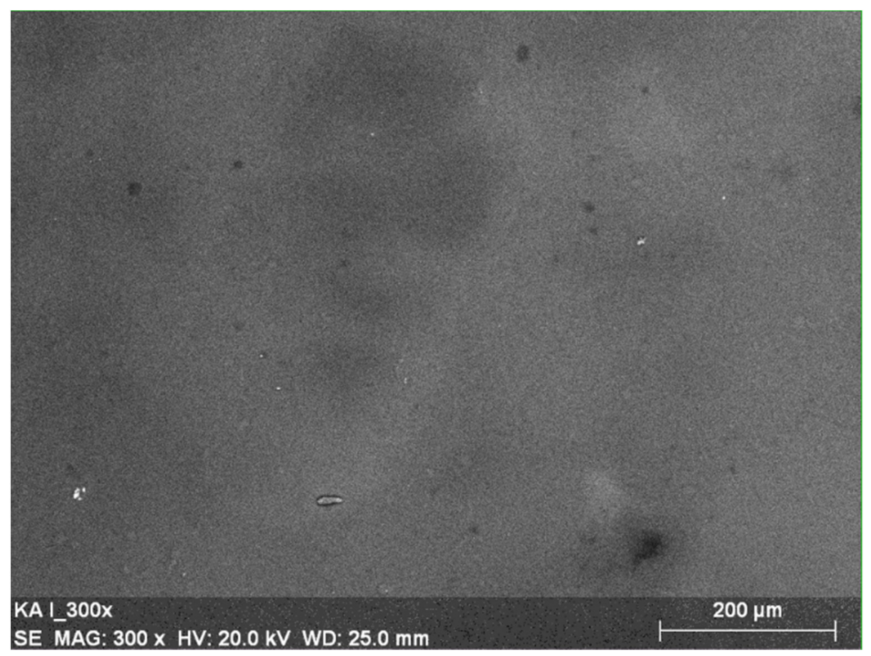

Figure 2. SEM image of collagen/melissa film.

Energy-Dispersive X-ray Spectroscopy (EDX) was conducted to examine the elemental composition of the material. The percentage elements range in the sample was measured and is presented in Figure 3 with proper voltage attribution represented in seconds per electron-volt at accelerating voltage range $(\mathrm{keV})$ for EDX analysis. The mean value of the mass percentage of $\mathrm{C}$ element in the Col/ML sample was $38.34 \%$, whereas for $\mathrm{N}$ it was $19.77 \%$, for $\mathrm{O}$ it was $39.72 \%$. The mass percentage in the control sample (collagen)was similar and indicated $37.79 \%$ of the C element, $21.22 \%$ for $\mathrm{N}$, and $39.76 \%$ for $\mathrm{O}$.

\subsection{Atomic Force Microscopy (AFM)}

Atomic Force Microscopy (AFM) was used to assess the material surface structure. The AFM image of the surface of collagen film is shown in Figure 4. In Figure 5 one can see the AFM visualization of the surface of collagen/melissa (Col/ML) film.

Root mean square average of height deviations $(\mathrm{Rq})$ for each film was measured. The $\mathrm{Rq}$ value of collagen film was $172.05 \mathrm{~nm}$, while for melissa-incorporated collagen film was $170.9 \mathrm{~nm}$. Values of $\mathrm{Ra}$ (the arithmetic roughness average of the surface) for collagen film and collagen film with melissa were $205.9 \mathrm{~nm}$ and $140 \mathrm{~nm}$, respectively. It has been proven that the addition of melissa changes the superficial properties of collagen films. The roughness of collagen films changes eminently as a result of melissa addition. 


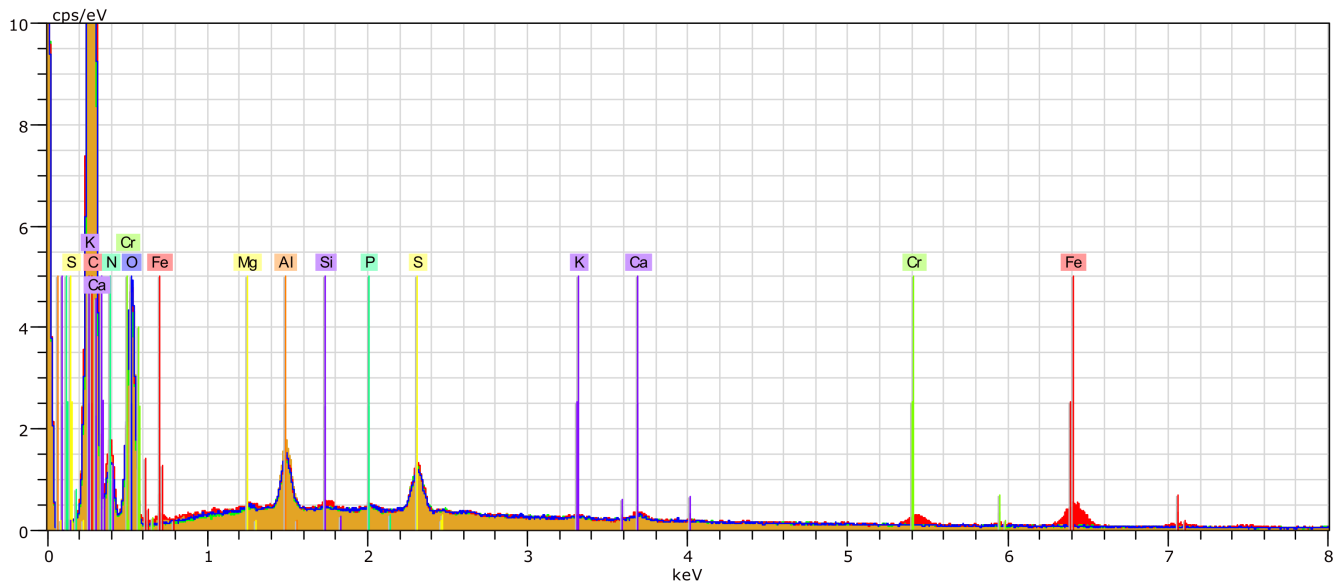

Figure 3. The percentage element range in sample collagen/melissa.

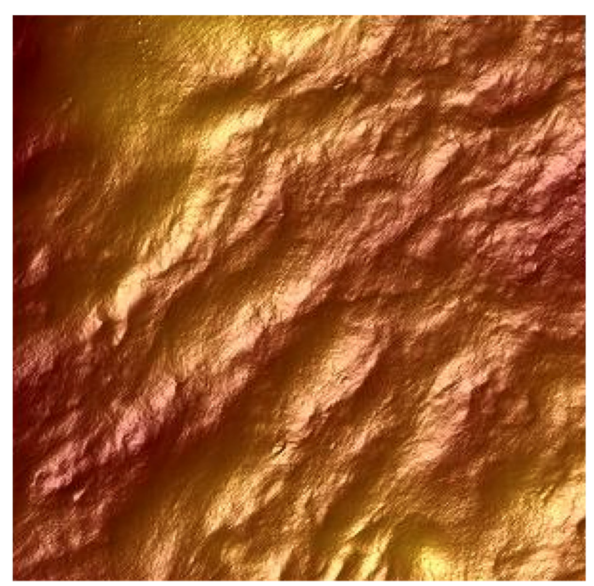

Figure 4. AFM visualization of collagen film (the roughness parameters were calculated from $10 \mu \mathrm{m} \times 10 \mu \mathrm{m}$ scanned areas).

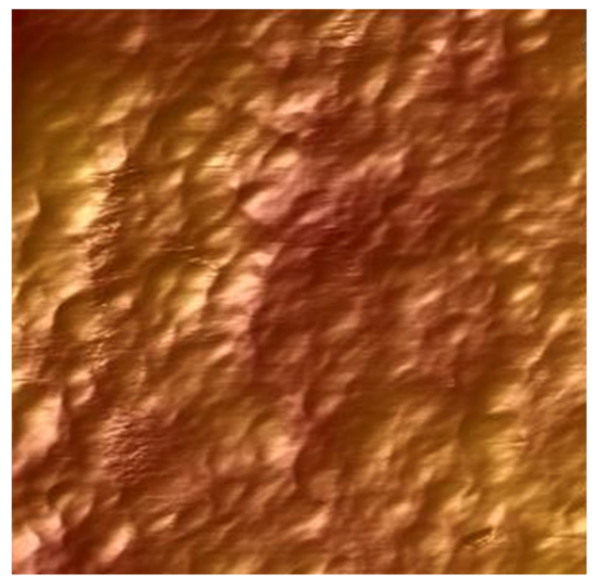

Figure 5. AFM visualization of Col/ML film (the roughness parameters were calculated from $10 \mu \mathrm{m} \times 10 \mu \mathrm{m}$ scanned areas).

\subsection{Mechanical Properties}

Tensile strength of collagen and melissa-incorporated collagen films were examined (Table 2). The arithmetic mean from seven samples was properly assessed for collagen film (41.7 MPa) and melissa-incorporated collagen film (9.8 MPa), which indicates that the addition of melissa decreases the mechanical properties of collagen films. 
Table 2. Mechanical properties of collagen and melissa-incorporated collagen film.

\begin{tabular}{ccc}
\hline Material & $\mathbf{F}_{\max }(\mathbf{M P a})$ & $\mathbf{E}_{\text {mod }}(\mathbf{G P a})$ \\
\hline Collagen & $41.7 \pm 9.31$ & $0.627 \pm 0.08$ \\
Collagen/Melissa & $9.8 \pm 6.16$ & $0.321 \pm 0.04$ \\
\hline
\end{tabular}

Based on mechanical properties measurement, the Young modulus was calculated. Results are presented in Table 2. The mean average of the Young modulus for collagen film was $0.627 \mathrm{GPa}$, whereas for melissa-incorporated collagen film it was $0.321 \mathrm{GPa}$. Tensile stiffness is weaker in collagen film with the addition of melissa. The decrease of the mechanical properties of collagen films after melissa addition indicates that the structure of the material has been changed. Mechanical properties of collagen film modified with melissa extract are much worse than for pure collagen films. It may suggest that hydrogen bonds between components of melissa extract are stronger than hydrogen bonds between melissa extract and collagen. The above results show that the addition of melissa to collagen does not improve the mechanical properties of collagen film. However, melissa is known for its antioxidant properties [53,54]. In the next step, the antioxidant properties of melissa-incorporated collagen films were assessed.

\subsection{Determination of Antioxidant Capacity}

3.5.1. Spectrophotometric Method for Determination of the Total Polyphenols Content of Using the Folin-Ciocalteu Reagent (F-C Method)

The Folin-Ciocalteau method is used to determine the content of phenolic compounds. The phenolic concentration can be read from the gallic acid (or caffeic) calibration curve, which is used as the phenol reference standard [55]. The reaction of gallic acid with molybdenum, a component of the Folin-Ciocalteu reagent, is presented in Figure 6.<smiles>O=C(O)c1cc(O)c(O)c(O)c1</smiles><smiles>O=C([O-])C1=CC(=O)C(=O)C(O)=C1</smiles>

Figure 6. Reaction of gallic acid with molybdenum, a component of the Folin-Ciocalteau reagent [55].

It is a simple and sensitive method; however, it is not selective, and the reaction is slow at low $\mathrm{pH}$. The Folin-Ciocalteau reagent can react with various compounds contained in the sample, especially sugars, aromatic amines, sulfur dioxide, ascorbic acid, and many other phenolic and non-phenolic compounds (e.g., amino acids, hydrazine, proteins, urea), which may ultimately affect the final result of the analysis of polyphenolic compounds $[55,56]$. The most important stage in this method is preparation a proper calibration curve for the experiment. For the Folin-Ciocalteu method, the data obtained for the calibration curve are collected in Table 3. Based on the obtained results, a standard curve was drawn as the dependence of the absorbance value on the concentration of caffeic acid (Figure 7). 
Table 3. Data obtained for the calibration curve.

\begin{tabular}{ccccccccc}
\hline Caffeic acid volume $(\mathbf{m L})$ & 0.10 & 0.20 & 0.30 & 0.50 & 0.60 & 0.70 & 0.80 \\
\hline Concentration $(\mathbf{m g} / \mathrm{L})$ & 0.50 & 0.10 & 0.15 & 0.25 & 0.30 & 0.35 & 0.40 \\
\hline Absorbance & 0.101 & 0.169 & 0.241 & 0.388 & 0.457 & 0.539 & 0.616 \\
\hline
\end{tabular}

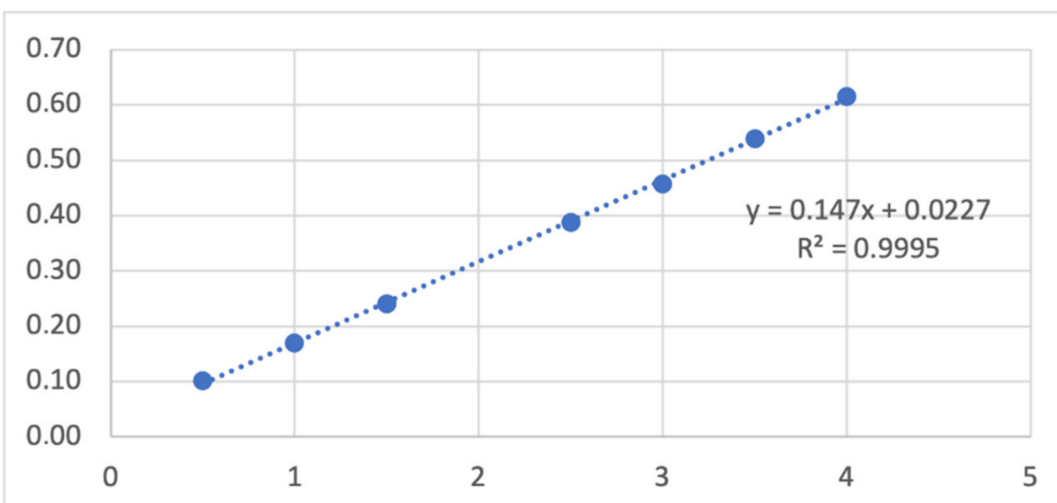

Figure 7. The calibration curve obtained by the F-C method (absorbance vs. caffeic acid concentration).

In Table 4 the statistical parameters of the calibration curve are presented.

Table 4. Statistical analysis of calibration curve.

\begin{tabular}{cc}
\hline Parameters & Value \\
\hline Curve slope a & $0.147 \pm 0.004$ \\
Curve intercept b & $0.0227 \pm 0.0096$ \\
Limit of detection LOD $(\mathrm{mg} / \mathrm{L})$ & 0.13 \\
Limit of quantification LOQ $(\mathrm{mg} / \mathrm{L})$ & 0.31 \\
Coefficient of determination $\mathrm{R}^{2}(\%)$ & 99.95 \\
\hline
\end{tabular}

Based on the parameters of the reference curve, the polyphenol content in terms of caffeic acid equivalent in the tested samples was calculated. The results are presented in Table 5.

Table 5. Obtained results with statistical evaluation.

\begin{tabular}{|c|c|c|}
\hline Parameters/Samples & $\begin{array}{c}\text { Collagen Control } \\
X_{\text {mean }} \pm \mathrm{SD}\end{array}$ & $\begin{array}{c}\text { Collagen/Meliss } \\
\mathrm{AX}_{\text {mean }} \pm \mathrm{SD}\end{array}$ \\
\hline $\mathrm{X}_{\text {mean }} \pm$ SD. mg CAE $/ \mathrm{g}$ & $8.22 \pm 1.9$ & $9.39 \pm 1.3$ \\
\hline
\end{tabular}

\subsubsection{Determination of Antioxidant Activity by FRAP Method}

The FRAP (ferric ion reducing antioxidant parameter) method was proposed by Benzie et al. in 1996 to determine the antioxidant activity of plasma, and a few years later, it was used to study plant antioxidants [56]. It is based on the determination of AA through the ability to reduce $\mathrm{Fe}^{3+}$ ions to $\mathrm{Fe}^{2+}$ ions under the influence of an antioxidant, and $\mathrm{Fe}(\mathrm{II})$ is complexed by TPTZ (2,4,6-tripyridyl-S-triazine) (Figure 8). The reduction reaction leads to the formation of a blue complex $(\lambda \max =595 \mathrm{~nm})[55,57]$. 

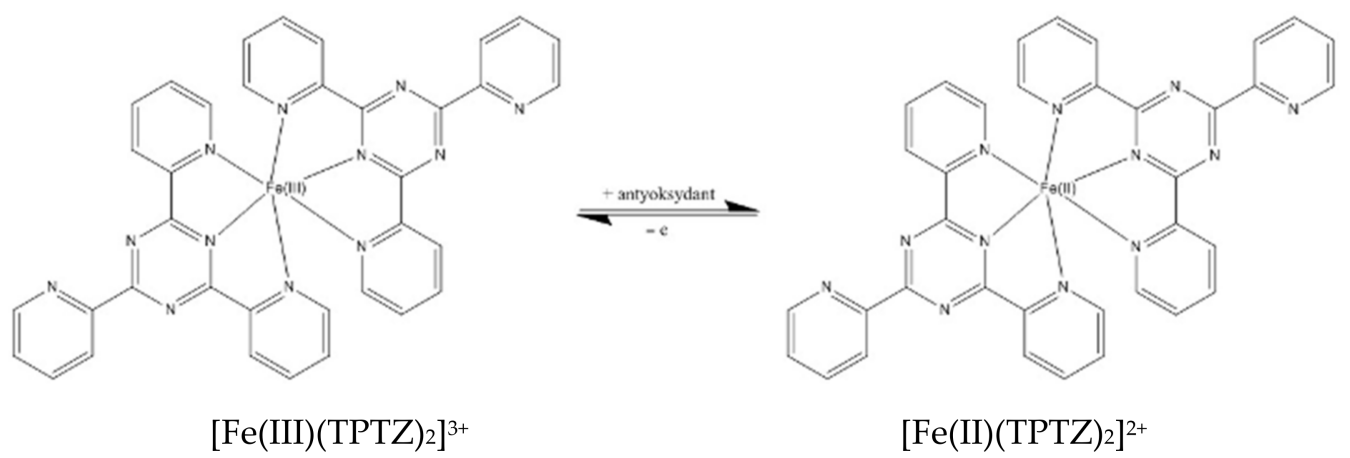

Figure 8. The schema of reaction in FRAP method [56].

AA is determined by comparing the value of the change in absorbance of the analyzed sample and the standard solution. The FRAP unit determines the ability to reduce 1 mole of $\mathrm{Fe}(\mathrm{III})$ to $\mathrm{Fe}(\mathrm{II})$. The change in the absorbance value is linear in a wide range of concentrations, which is the advantage of this method [57]. The optimum $\mathrm{pH}$ for this method, necessary to stabilize the iron ions, is 3.6, and the redox potential of the samples must be lower than $0.7 \mathrm{~V}$ because the redox potential of $\left[\mathrm{Fe}(\mathrm{TPTZ})_{2}\right]^{3+} /\left[\mathrm{Fe}(\mathrm{TPTZ})_{2}\right]^{2+}$ is $0.7 \mathrm{~V}$.

The FRAP method does not require time-consuming sample preparation, is simple and quick to perform, and ensures repeatability of the obtained results. FRAP has been used in the determination of the antioxidant capacity of cells and tissues; however, it cannot measure the main thiol antioxidant-glutathione. Moreover, Fe(II) ions are easily oxidized, creating a very harmful $\mathrm{OH}^{\bullet}$ radical [56].

The results obtained for the reference curve have been shown in Table 6 .

Table 6. Data obtained for the calibration curve.

\begin{tabular}{cccccc}
\hline Trolox volume $\left(\mathbf{c m}^{3}\right)$ & 0.05 & 0.10 & 0.15 & 0.20 & 0.25 \\
\hline Concentration $(\mathbf{m g} / \mathbf{L})$ & 0.0125 & 0.025 & 0.0375 & 0.0501 & 0.0626 \\
\hline Absorbance & 0.153 & 0.390 & 0.643 & 0.863 & 1.115 \\
\hline
\end{tabular}

Based on the obtained results, the dependence of the absorbance value on the concentration of Trolox was plotted (Figure 9). In Table 7, the statistical parameters of the calibration curve are presented.

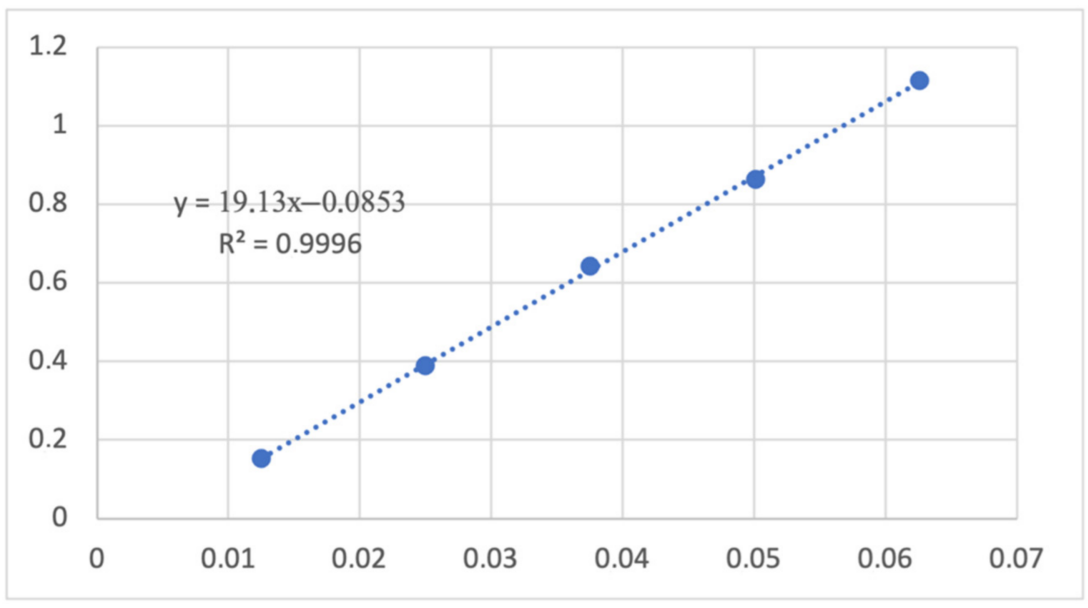

Figure 9. The calibration curve for FRAP method (absorbance vs. Trolox concentration). 
Table 7. Statistical analysis of calibration curve.

\begin{tabular}{cc}
\hline Parameter & Value \\
\hline Curve slope a & $19.13 \pm 0.72$ \\
Curve intercept b & $0.0853 \pm 0.0297$ \\
Limit of detection LOD $(\mathrm{mg} / \mathrm{L})$ & 0.0024 \\
Limit of quantification LOQ $(\mathrm{mg} / \mathrm{L})$ & 0.0059 \\
Coefficient of determination $\mathrm{R}^{2}(\%)$ & 99.96 \\
\hline
\end{tabular}

Based on the parameters of the calibration curve, the total antioxidant content in terms of Trolox equivalent in the tested samples were calculated. The results have been shown in Table 8.

Table 8. Obtained results with statistical evaluation.

\begin{tabular}{|c|c|c|}
\hline Parameters/Samples & $\begin{array}{c}\text { Collagen Control } \\
X_{\text {mean }} \pm \text { SD }\end{array}$ & $\begin{array}{c}\text { Collagen/Meliss } \\
\mathrm{AX}_{\text {mean }} \pm \mathrm{SD}\end{array}$ \\
\hline $\mathrm{X}_{\text {mean }} \pm$ SD. mg TE/g & $0.10 \pm 0.01$ & $0.63 \pm 0.07$ \\
\hline
\end{tabular}

\subsubsection{Determination Antioxidant Activity by CUPRAC Method}

The CUPRAC (cupric ion reducing antioxidant capacity) method is based on the same operating mechanism as the FRAP method. In the CUPRAC method, copper ions are reduced instead of iron ions. Under the influence of antioxidants in the tested sample, the copper(II) complex is reduced to a colored copper(I) complex, for which the absorbance value is measured spectrophotometrically. In this method, two compounds are used interchangeably: (a) bathocuproine (2,9-dimethyl-4,7-diphenyl-1,10-phenanthroline) as a copper(I) complexing compound in a ratio of 2:1 to form an orange complex with an absorption maximum at $490 \mathrm{~nm}$; (b) neocuproine (2,9-dimethyl-1,10-phenanthroline) forming yellow-orange complexes with copper(I), the highest absorbance of which is at $450 \mathrm{~nm}$ [58] (Figure 10).

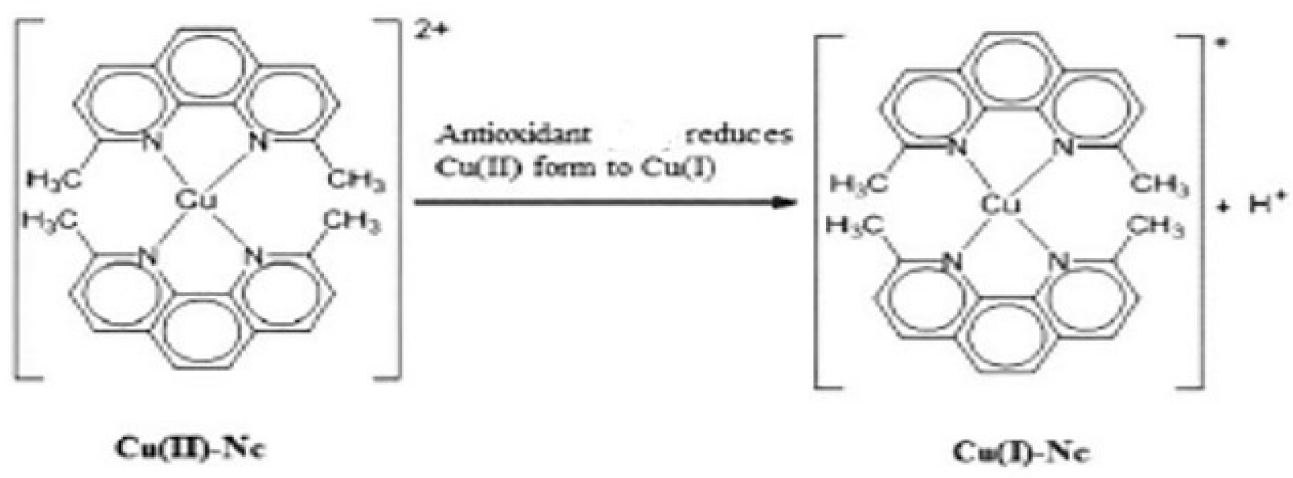

Figure 10. The schema of reaction in the CUPRAC method [58].

Antioxidant activity is expressed as the amount of uric acid, caffeic acid equivalents in the sample or in Trolox equivalents. The redox potential of the $\mathrm{Cu}(\mathrm{II})-\mathrm{Nc} / \mathrm{Cu}(\mathrm{I})-\mathrm{Nc}$ complex is $0.6 \mathrm{~V}$ and is higher than the standard $\mathrm{Cu}(\mathrm{II}) / \mathrm{Cu}(\mathrm{I})-0.16 \mathrm{~V}$ potential, which positively affects the speed and efficiency of polyphenol oxidation. The CUPRAC method is quick, easy, and selective. It allows the determination of hydrophobic and hydrophilic antioxidants as well as compounds contained in samples of plant origin and thus well reflects the total power of antioxidants contained in the sample. It does not require the use of an acidic reaction medium (such as FRAP) or basic (as in the F-C method) [55,58].

The results obtained for the calibration curve by CUPRAC method have been shown in Table 9. 
Table 9. Data obtained for the calibration curve.

\begin{tabular}{cccccc}
\hline Caffeic acid solution $(\mathrm{mL})$ & 0.05 & 0.10 & 0.25 & 0.30 & 0.35 \\
\hline Concentration $(\mathbf{m g} / \mathrm{L})$ & 0.425 & 0.850 & 2.125 & 2.550 & 2.975 \\
\hline Absorbance & 0.296 & 0.406 & 0.790 & 0.902 & 1.015 \\
\hline
\end{tabular}

Based on the obtained results, the dependence of the absorbance value on the concentration of caffeic acid was plotted (Figure 11). In Table 10, the statistical parameters of the calibration curve are presented.

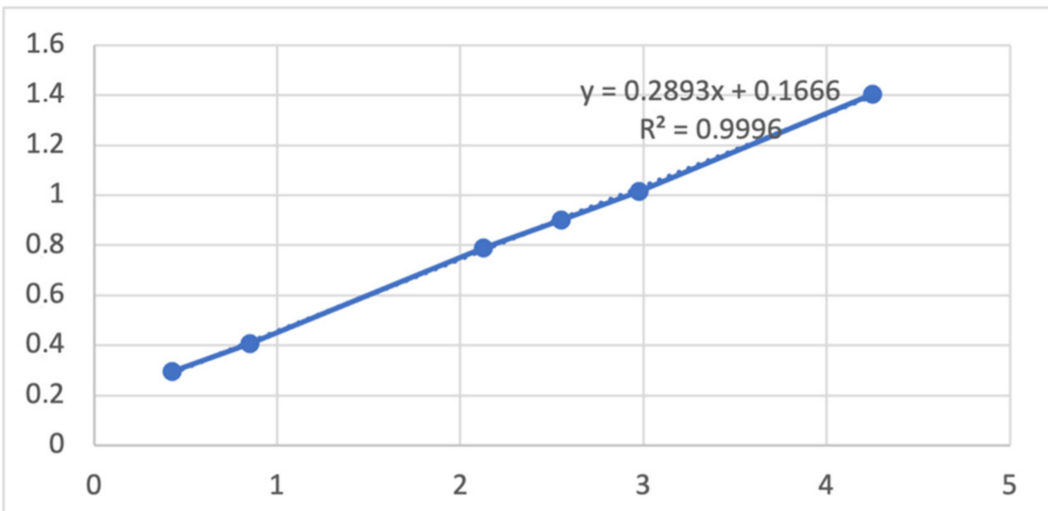

Figure 11. The calibration curve for the CUPRAC method (absorbance vs. caffeic acid concentration).

Table 10. Statistical analysis of calibration curve.

\begin{tabular}{cc}
\hline Parameter & Value \\
\hline Curve slope a & $0.2893 \pm 0.0084$ \\
Curve intercept b & $0.1666 \pm 0.0213$ \\
Limit of detection LOD $(\mathrm{mg} / \mathrm{L})$ & 0.14 \\
Limit of quantification LOQ $(\mathrm{mg} / \mathrm{L})$ & 0.32 \\
Coefficient of determination $\mathrm{R}^{2}(\%)$ & 99.96 \\
\hline
\end{tabular}

Based on the parameters of the calibration curve, the total antioxidant content in terms of caffeic acid equivalent in collagen and collagen/melissa films were calculated and presented in Table 11.

Table 11. Obtained results with statistical evaluation.

\begin{tabular}{|c|c|c|}
\hline Parameters/Samples & $\begin{array}{c}\text { Collagen Control } \\
X_{\text {mean }} \pm S D\end{array}$ & $\begin{array}{c}\text { Collagen/Meliss } \\
\mathrm{AX}_{\text {mean }} \pm \mathrm{SD}\end{array}$ \\
\hline $\mathrm{X}_{\text {mean }} \pm \mathrm{SD} \cdot \mathrm{mg} \mathrm{CAE} / \mathrm{g}$ & $2.42 \pm 0.2$ & $17.95 \pm 2.1$ \\
\hline
\end{tabular}

$\mathrm{CAE}$-caffeic acid equivalent; $X_{\text {mean }}$-average value; SD—standard deviation.

\subsubsection{Determination of Antioxidant Activity by the DPPH Method}

This method uses a strong and stable DPPH radical (2,2'-diphenyl-1-picrylhydrazyl), which in an alcoholic solution has an intense purple color with maximum absorption at a wavelength of $517 \mathrm{~nm}$ (for a methanol solution) (Figure 12). The DPPH radical captures electrons from substances with antioxidant properties, which causes the color of the solution to change from violet to yellow, and the absorbance of the tested sample decreases, which is measured spectrophotometrically. The stronger the antioxidant properties of a given sample, the greater the decrease in absorbance reflecting the reduction of the DPPH radical [59]. 


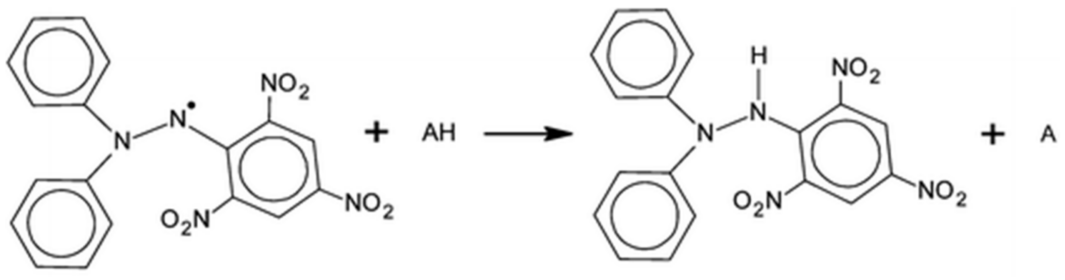

Figure 12. Reaction between DPPH and antioxidant [60].

The antioxidant activity of test samples is expressed as the percentage of reduction of the DPPH radical by the sample with respect to the control sample. The content of antioxidants can also be expressed as the amount of reference substance equivalents (e.g., Trolox, ascorbic acid) or as the degree of DPPH radical scavenging [59,60]. This method is fast and accurate. The obtained results are reproducible and comparable with the results obtained by other methods. It is widely used to measure the antioxidant capacity of natural raw materials such as fruit, juices, food, and plant extracts [59].

The result of measurement by DPPH method are presented in Table 12.

Table 12. Data obtained for the calibration curve.

\begin{tabular}{cccccc}
\hline Trolox concentration $(\mathrm{mg} / \mathrm{L})$ & 0.4984 & 1.9936 & 3.4888 & 3.9870 & 4.9840 \\
\hline Absorbance & 0.861 & 0.406 & 0.790 & 0.902 & 1.015 \\
\hline \% DPPH & 6.16 & 24.16 & 41.82 & 49.01 & 60.63 \\
\hline
\end{tabular}

In Figure 13 the dependence of the percentage of the scavenged radical on Trolox concentration is presented.

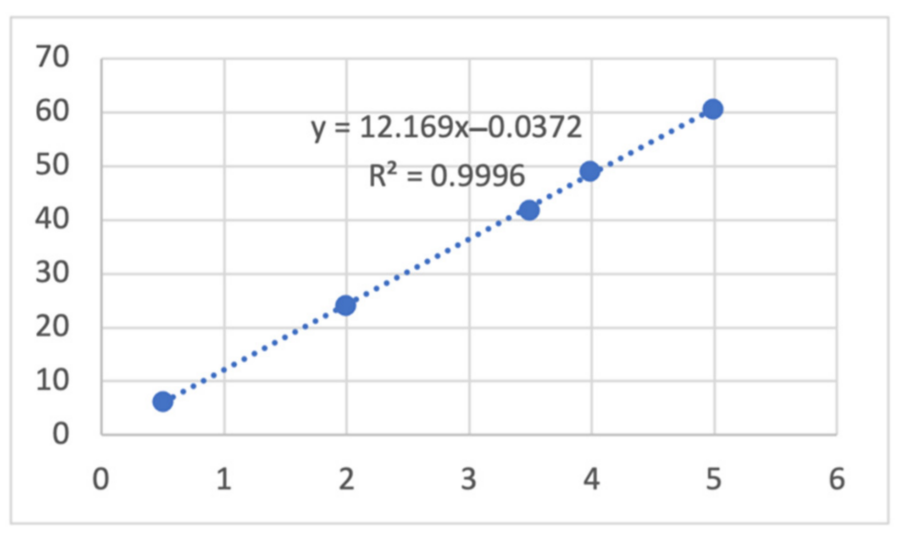

Figure 13. The dependence of the percentage of the scavenged radical on Trolox concentration (\%DPPH vs. Trolox concentration).

Statistical analysis of the performed results is presented in the Table 13.

Table 13. Statistical analysis of calibration curve.

\begin{tabular}{cc}
\hline Parameter & Value \\
\hline Curve slope a & $12.169 \pm 0.427$ \\
Curve intercept $\mathrm{b}$ & $-0.0372 \pm 1.4444$ \\
Limit of detection LOD $(\mathrm{mg} / \mathrm{L})$ & 0.19 \\
Limit of quantification LOQ $(\mathrm{mg} / \mathrm{L})$ & 0.46 \\
Coefficient of determination $\mathrm{R}^{2}(\%)$ & 99.96 \\
\hline
\end{tabular}

Based on the parameters of the calibration curve, the total antioxidant content in terms of Trolox equivalent in the tested samples were calculated (Table 14). 
Table 14. Obtained results with statistical evaluation.

\begin{tabular}{ccc}
\hline Parameters/Samples & $\begin{array}{c}\text { Collagen Control } \\
\boldsymbol{X}_{\text {mean }} \pm \text { SD }\end{array}$ & $\begin{array}{c}\text { Collagen/Meliss } \\
\text { AX }\end{array}$ \\
\hline$X_{\text {mean }} \pm$ SD. $\mathrm{mg}$ TE $/ g$ & $0.62 \pm 0.06$ & $2.90 \pm 0.23$ \\
\hline TE-Trolox equivalent; $X_{\text {mean }}$-average value; SD—standard deviation.
\end{tabular}

Antioxidant activity of collagen/melissa based materials has been proved by several independent methods. The antioxidative properties can be promising for future applications in cosmetics.

\section{Discussion}

Melissa officinalis exhibits several properties which can be used in biomaterial preparation $[53,54]$. The increasing attention of topical application of Melissa officinalis extracts and oils as novel antimicrobial and antiviral pharmaceuticals induce research on the incorporation of Melissa officinalis in natural biomaterials, which will be compatible with human skin, and comprise a matrix for the active substance. In this research, we tried to obtain collagen material modified by melissa. The performed infrared spectroscopy analysis confirmed the presence of collagen and indicated a band at $1377 \mathrm{~cm}^{-1}$, which represents $\mathrm{O}-\mathrm{H}$ stretching in carboxylic acid and $\mathrm{O}-\mathrm{H}$ band phenol group present in rosmaric, gallic, and phenolic acid in the Melissa officinalis extract. The shift of amide A observed in the collagen and Melissa officinalis sample may be caused by creating the hydrogen bonds between the natural extract and collagen. As mechanical properties of collagen films were worse after the addition of melissa, we can conclude that only weak hydrogen bonds can be formed between collagen and components of melissa, so melissa is not a good cross-linking agent for collagen. The performed Atomic Force Microscopy proved that the addition of melissa modifies superficial and film-forming properties of collagen. The roughness of collagen films varied depending on Melissa officinalis addition. It may influence the adhesion of collagen to the skin.

The research on the antioxidant activity of collagen films without the extract and with lemon balm extract clearly shows that biologically active compounds with an antioxidant nature have been associated with the collagen matrix without losing their properties. This increases the potential anti-aging effect of the collagen film on the skin surface. The antioxidant activity (AA) determines the ability of the tested material to counteract a specific oxidation reaction, i.e., it determines the measure of the ability of the substance to delay oxidative processes. This value describes the antioxidant properties of a given system better than the concentrations of all antioxidants contained in the sample determined separately [55]. Radical scavenging activity is significant because of the damaging role of free radicals to the skin, food, and biological systems. Tests based on the capacity to scavenge free radicals employ diverse radical-generating methods for detection of the oxidation end point. Using in vitro assays such as FC, FRAP, CUPRAC, and DPPH the antioxidant activity of Melissa officinalis was confirmed. The antioxidant ability of Melissa officinalis may be utilized as an effective factor in anti-aging cosmetics. As the literature has shown, such materials like silk fibroin, mulberry, and melissa constitutes potential antioxidative ingredients for cosmetic products [61] as well as Lentinus edodes, Acacia dealbata flowers, or grape pomace [62]. Confirmation of the antioxidant activity and the proper choice of active plant extract as well as synergic effect with other ingredients in the cosmetic formulation comprises an important factor to create an effective cosmetic product. The quantity of the Melissa officinalis extract used in this study modifies the structure of collagen films and changes its superficial and mechanical properties. The variety of natural active substances present in the Melissa officinalis extract makes it the valuable agent of broad application in the fields of cosmetics, pharmacy, and medicine. When creating a biomaterial including Melissa officinalis extract, it should be taken into account that the hydrogen bonds created among the gallic acid, phenolic acid, and rosmaric acid may be the reason for the impediments in forming a new biomaterial. 


\section{Conclusions}

Melissa officinalis extract can be incorporated into collagen solutions and films. However, the results showed that the addition of melissa extract led to the decrease of mechanical properties of collagen films. Tensile strength of melissa-incorporated collagen films is significantly lower than in collagen film, likewise for tensile stiffness. The addition of melissa extract slightly modifies the superficial properties of collagen films. The decrease of mechanical properties and only slight modification of the surface properties are probably caused by hydrogen bonding between melissa components, and only part of them can form hydrogen bonds with collagen. The addition of melissa to collagen leads to materials with antioxidant activity, which can be potentially useful in anti-aging cosmetic products. Further research is required to study biological activity and the cosmetic potential of melissa extract incorporated collagen films.

Author Contributions: Conceptualization, A.S., K.A. and M.K.; methodology, A.S. and M.K.; software, A.S., K.A. and M.K.; validation, A.S., K.A. and M.K.; formal analysis, A.S.; investigation, K.A. and M.K.; resources, A.S. and K.A.; data curation, K.A., A.S. and M.K.; writing-original draft preparation, K.A., M.K. and A.S.; writing-review and editing, A.S. and K.A.; visualization, K.A.; supervision, A.S.; project administration, A.S.; funding acquisition, A.S. All authors have read and agreed to the published version of the manuscript.

Funding: This research received no external funding.

Institutional Review Board Statement: Ethical review and approval were waived for this study, due to the fact that we used the waste of food production.

Informed Consent Statement: Not applicable.

Data Availability Statement: The data presented in this study are available on request from the corresponding author.

Conflicts of Interest: There are no conflict to declare.

Sample Availability: Samples of the compounds are not available from the authors.

\section{References}

1. Chi, L.; Anuj, S.; Yugyung, L. Biomedical applications of collagen. Int. J. Pharm. 2001, 221, 1-22.

2. Cen, L.; Liu, W.; Cui, L.; Zhang, W.; Cao, Y. Collagen tissue engineering: Development of novel biomaterials and applications. Pediatr. Res. 2008, 63, 492-496. [CrossRef] [PubMed]

3. Patino, M.; Neiders, M.; Andreana, S.; Noble, B.; Cohen, R. Collagen as an implantable material in medicine and dentistry. J. Oral Implantol. 2002, 28, 220-225. [CrossRef]

4. Stenzel, K.; Miyata, T.; Rubin, A. Collagen as a biomaterial. Annu. Rev. Biophys. Bioeng. 1974, 3, 231-253. [CrossRef] [PubMed]

5. Shekhter, A.; Fayzullin, M.; Vukulova, M.; Rudenko, M.; Osipycheva, T. Medical applications of collagen and collagen-based materials. Curr. Med. Chem. 2019, 26, 506-516. [CrossRef] [PubMed]

6. Rich, A.; Crick, F. The molecular structure of collagen. J. Mol. Biol. 1961, 3, 483-506. [CrossRef]

7. Bornstein, P. Structurally distinct collagen types. Annu. Rev. Bioch. 1980, 49, 957-1003. [CrossRef]

8. Mark, K. Localization of collagen types in tissues. Int. Rev. Connect. Tissue Res. 1981, 9, 265-324.

9. Burgeson, R.; Nimni, M. Collagen types. Molecular structure and tissue distribution. Clin. Orthop. Relat. Res. 1992, 282, $250-272$.

10. Bella, J. Collagen structure: New tricks from a very old dog. Biochem. J. 2016, 473, 1001-1025. [CrossRef]

11. Ramachandran, G. Stereochemistry of collagen. Int. J. Pep. Protein Res. 1988, 31, 1-16. [CrossRef]

12. Bella, J.; Brodsky, B.; Berman, H. Hydration structure of collagen peptide. Structure 1995, 3, 893-906. [CrossRef]

13. Parry, D. The molecular fibrillar structure of collagen and its relationship to the mechanical properties of connective tissue. Biophys. Chem. 1988, 29, 195-209. [CrossRef]

14. Patino, M.; Neiders, M.; Andreana, S.; Noble, B.; Cohen, R. Collagen: An overview. Implant. Dent. 2002, 11, 280-285. [CrossRef]

15. Nimni, M. Collagen: Structure, function, and metabolism in normal and fibrotic tissues. Semin. Arthritis Rheum. 1983, 13, 1-86. [CrossRef]

16. Han, S.; Makareeva, E.; Kuznetsova, N.; Deridder, A.; Sutter, M.; Losert, W.; Phillips, C.; Visse, R.; Nagase, H.; Leikin, S. Molecular mechanism of Type I collagen homotrimer resistance to mammalian collagenases. J. Biol. Chem. 2010, 185, 22276-22281. [CrossRef]

17. Mimica-Dukic, N.; Bozin, B.; Sokovic, M.; Simin, N. Antimicrobioal and antioxidant activities of Melissa officinalis, L. (Lamiaceae) Essential. J. Agric. Food Chem. 2004, 5, 2485-2489. [CrossRef] [PubMed] 
18. Miraj, S.; Kopaei, R.; Kiani, S. Melissa officinalis L: A review study with an antioxidative prospective. Evid. Based Complement. Altern. Med. 2017, 22, 385-394. [CrossRef] [PubMed]

19. Burns, A.; Perry, E.; Holmes, C.; Francis, P.; Morris, J.; Howes, M.; Chazot, G.; Ballard, C. A double-blind placebo-controlled randomized trial of Melissa officinalis oil and donepezil for the treatment of agitation in Alzheimer's disease. Dement. Geriatr. Cogn. 2011, 31, 158-164. [CrossRef]

20. Asadbeigi, M.; Mohammadi, T.; Rafieian-Kopaei, M.; Saki, K.; Bahmani, M.; Delfan, M. Traditional effects of medicinal plants in the treatment of respiratory diseases and disorders: An ethnobotanical study in the Urmia. Asian Pac. J. Trop. Med. 2014, 7, 364-368. [CrossRef]

21. Dastmalchi, K.; Dorman, H.; Oinonen, P.; Darwis, Y.; Laakso, I.; Hiltunen, R. Chemical composition and in vitro antioxidative activity of a lemon balm (Melissa officinalis L.) extract. LWT Food Sci. Technol. 2008, 41, 391-400. [CrossRef]

22. Amin, G.; Pharm, A.; Vosough, S.; Azar, Z.; Shariat, M.; Haghollahi, F.; Afshar, S. Therapeutic effect of combination of Nigella sativa, Melissa officinalis extract and fennel fruit with citalopram on menopausal symptoms. Tehran Univ. Med. J. 2018, 76, 417-425.

23. Joukar, S.; Zarisfi, Z.; Sepehri, G.; Bashiri, A. Efficacy of Melissa officinalis in suppressing ventricular arrhythmias following ischemia-reperfusion of the heart: A comparison with amiodarone. Med. Princ. Pract 2012, 23, 340-345. [CrossRef]

24. Saberi, A.; Abbasioo, E.; Sepehri, G.; Yazdanpanah, M.; Mirkamandari, E.; Sheibani, V.; Safi, Z. The effects of methanolic extract of Melissa officinalis on experimental gastric ulcers in rats. Iran. Red Crescent Med. J. 2016, 18, 24271. [CrossRef] [PubMed]

25. Delfan, B.; Bahmani, M.; Eftekhari, Z. Effective herbs on the wound and skin disorders: A ethnobotanical study in Lorestan province, west of Iran. Asian Pac. J. Trop. Dis. 2014, 4, 938-942. [CrossRef]

26. Saki, K.; Bahmani, M.; Rafieian-Kopaei, M. The effect of most important medicinal plants on two important psychiatric disorders (anxiety and depression)—A review. Asian Pac. J. Trop. Med. 2014, 7, 34-42. [CrossRef]

27. Saki, K.; Bahmani, M.; Rafieian-Kopaei, M. The most common native medicinal plants used for psychiatric and neurological disorders in Urmia city, northwest of Iran. Asian Pac. J. Trop. Dis. 2014, 4, 895-901. [CrossRef]

28. Bahmani, M.; Tajeddini, P.; Ezatpour, B.; Rafieian-Kopaei, M.; Naghdi, N.; Asadi-Samani, M. Ethenobothanical study of medicinal plants against parasites detected in Shiraz, southern part of Iran. Der Pharm. Lett. 2016, 8, 153-160.

29. Bahmani, M.; Karamati, S.; Hassanzadazar, H. Ethnobotanic study of medicinal plants in Urmia city: Identification and traditional using of antiparasites plants. Asian Pac. J. Trop. Dis. 2014, 4, 906-910. [CrossRef]

30. Canadanovic-Brunet, J.; Cetkovic, G.; Djilas, S. Radical scavenging, antibacterial, and antiproliferative activities of Melissa officinalis L. extracts. J. Med. Food. 2008, 11, 133-143. [CrossRef] [PubMed]

31. Triantaphyllou, K.; Blekas, G.; Boskou, D. Antioxidative properties of water extracts obtained from herbs of the species Lamiaceae. Int. J. Food Sci. Nutr. 2001, 52, 313-317. [CrossRef] [PubMed]

32. Ferreira, A.; Proenca, C.; Serralheiro, M.; Araujo, M. The in vitro screening for acetylcholinesterase inhibition and antioxidant activity of medicinal plants from Portugal. J. Ethnopharmacol. 2006, 108, 31-37. [CrossRef] [PubMed]

33. Sentkowska, A.; Biesaga, M.; Pyrzynska, K. Polyphenolic composition and antioxidative properties of lemon balm (Melissa officinalis L.) extract affected by different brewing processes. Int. J. Food Prop. 2014, 18, 2009-2014. [CrossRef]

34. Ribeiro, M.; Bernardo-Gil, M.; Esquivel, M. Melissa officinalis L.: Study of antioxidant activity in supercritical residues. J. Supercrit. Fluids 2001, 21, 51-60. [CrossRef]

35. Sofowora, A.; Ogunbodede, E.; Onayade, A. The role and place of medicinal plants in the strategies for disease prevention. Afr. J. Tradit. Complement. Altern. Med. 2013, 10, 210-229. [CrossRef] [PubMed]

36. Gurčík, L'; Dúbravská, R.; Miklovičová, J. Economics of the cultivation of Salvia officinalis and Melissa officinalis. Agric. Econ. Czech. 2005, 51, 348-356. [CrossRef]

37. Schnitzler, P.; Schuhmacher, A.; Astani, A.; Reichling, J. Melissa officinalis oil affects infectivity of enveloped herpesviruses. Phytomedicine 2008, 15, 734-740. [CrossRef]

38. Koksal, E.; Bursal, E.; Dikic, E.; Tozoglu, F.; Gulcin, I. Antioxidant activity of Melissa officinalis leaves. J. Med. Plant Res. 2011, 5, 217-222.

39. Astani, A.; Reichling, J.; Schnitzler, P. Melissa officinalis extract inhibits attachment of herpes simplex virus in vitro. Chemotherapy 2012, 58, 70-77. [CrossRef] [PubMed]

40. Mazzanti, G.; Battinelli, L.; Pompeo, C.; Serrilli, A.M.; Rossi, R.; Sauzullo, I.; Mengoni, F.; Vullo, V. Inhibitory activity of Melissa officinalis L. extract on herpes simplex virus type 2 replication. Nat. Prod. Res. 2008, 22, 1433-1440.

41. Stefanović, O.; Comic, L. Synergistic antibacterial interaction between Melissa officinalis extracts and antibiotics. J. Appl. Pharm. Sci. 2012, 2, 1-5.

42. Wolbling, R.; Leonhardt, K. Local therapy of herpes simplex with dried extract from Melissa officinalis. Phytomedicine 1994, 1, 25-31. [CrossRef]

43. Iauk, L.; Bue, A.; Milazzo, I.; Rapisarda, A.; Blandino, G. Antibacterial activity of medicinal plant extracts against periodontopathic bacteria. Phytother. Res. 2003, 17, 599-604. [CrossRef] [PubMed]

44. Koytchev, R.; Alken, R.; Dundaro, E. Antibacterial and antifungal activity of ethanolic extracts from eleven spice plants. Biologia 2006, 61, 275-278.

45. Sariyar, E.; Adsersen, G.; Karakoc, A.; Otük, B.; Oktayoglu, G.; Pirildar, E. Traditional medicine in Sakarya province (Turkey) and antimicrobial activities of selected species. J. Ethnopharmacol. 2004, 95, 287-296. 
46. Bounihi, A.; Hajjaj, G.; Alnamer, R.; Cherrah, Y.; Zellou, A. In vivo potential anti-inflammatory activity of Melissa officinalis L. essential oil. Adv. Pharmacol. Sci. 2013, 2013, 101759. [PubMed]

47. Sionkowska, A.; Lewandowska, K.; Adamiak, K. The influence of UV light on rheological properties of collagen extracted from Silver Carp skin. Materials 2020, 13, 4453. [CrossRef]

48. Barnes, J.; Anderson, L.A.; Phillipson, J.D. Herbal Medicines: A Guide for Healthcare Professionals, 2nd ed.; Pharmaceutical Press: London, UK, 2002.

49. Gopaul, R.; Knaggs, H.; Lephart, J.; Holley, K.; Gibson, E. Original contribution: An evaluation of the effect of a topical product 332 containing salicin on the visible signs of human skin aging. J. Cosmet. Dermatol. 2010, 9, 196-291. [CrossRef]

50. Adamiak, K.; Lewandowska, K.; Sionkowska, A. The influence salicin on rheological and film forming properties of collagen. Molecules 2021, 26, 1661. [CrossRef] [PubMed]

51. Bajer, D.; Janczak, K.; Bajer, K. Novel starch/chitosan/aloe vera composites as promising biopackaging materials. J. Polym. Environ. 2020, 28, 1021-1039. [CrossRef]

52. Andonegi, M.; Irastorza, A.; Izeta, A.; Caba, K.; Guerrero, P. Physicochemical and biological performance of aloe vera-incorpo-338 rated native collagen films. Pharmaceutics 2020, 12, 1173. [CrossRef]

53. Pressi, G.; Bertaiola, O.; Guarnerio, C.; Barbieri, E.; Guzzo, F.; Dura, C. In vitro cultured Melissa officinalis cells as effective ingredient to protect skin against oxidative stress, blue light, and infrared irradiations damages. Cosmetics 2021, 8, 23. [CrossRef]

54. Yong, J.; Hwan, L.; Haney, P.; Suyeong, K. Studies on antioxidant, anti-inflammation and tyrosinase inhibitory activities of Melissa officinalis extracts and their fractions. J. Soc. Cosmet. Sci. Korea 2018, 4, 465-474.

55. Singleton, V.; Orthofer, R.; Lamuela-Raventos, R.M. Analysis of total phenolics with phosphomolybdic_phosphotungstic acid reagent. Methods Enzymol. 1999, 299, 152-178.

56. Prior, R.; $\mathrm{Wu}, \mathrm{X}$.; Schaich, K. Standardized methods for the determination of antioxidant capacity and phenolics in food and dietary supplements. J. Agric. Food Chem. 2005, 53, 4290-4302. [CrossRef] [PubMed]

57. Antolovich, M.; Prenzler, P.; Patsalides, E.; McDonald, S.; Robards, K. Methods for testing antioxidant activity. Analyst 2002, 127, 183-198. [CrossRef]

58. Apak, A.; Güçlü, K.; Özyürek, M.; Çelik, S. Mechanism of antioxidant capacity assays and the CUPRAC (cupric ion reducing antioxidant capacity) assay. Microchim. Acta 2008, 160, 413-419. [CrossRef]

59. Szabo, M.; Iditoiu, C.; Chambre, D.; Lupea, A. Improved DPPH determination for antioxidant activity spectrophotometric assay. Chem. Pap. 2007, 61, 214-216. [CrossRef]

60. Pyrzynska, K.; Pękal, A. Application of free radical diphenylpicrylhydrazyl (DPPH) to estimate the antioxidant capacity of food samples. Anal. Methods 2013, 5, 4288-4295. [CrossRef]

61. Channarong, S.; Wassanai, W. Development of natural facial mask for skincare from local materials. IOP Conf. Ser. Mater. Sci. Eng. 2019, 635, 012003.

62. Soto, M.; Parada, M.; Falque, E.; Dominguez, H. Personal care products formulated with natural antioxidant extracts. Cosmetics 2018, 5, 13. [CrossRef] 